Mitteilungen der Österreichischen Geographischen Gesellschaft, 162. Jg., S. 91-121

(Annals of the Austrian Geographical Society, Vol. 162, pp. 91-121)

Wien (Vienna) 2020, https://doi.org/10.1553/moegg162s91

\title{
From Exception to Norm? Analysing Gated Housing In Sofia ANd KIEv SINCE 1989
}

\author{
Christian Smigiel, Salzburg, Kostyantyn MeZENTSEV, and \\ Nataliia PrOvOTAR, both Kiev [Kyiv]* \\ Initial submission / erste Einreichung: 05/2020; revised submission / revidierte Fassung: 08/2020; \\ final acceptance / endgültige Annahme: 11/2020 \\ with 3 figures in the text
}

\section{CONTENTS}

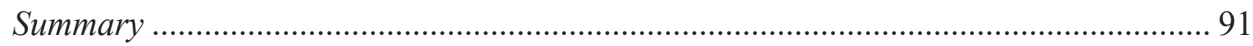

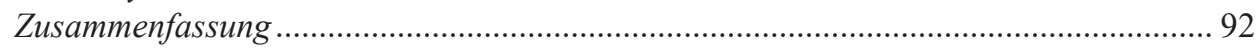

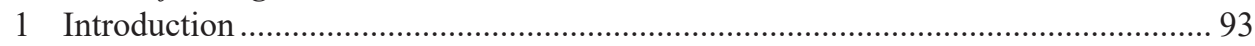

2 The framework for gated housing in (South-)Eastern Europe ................................... 94

3 Until 2008: The story of gated housing in Sofia and Kiev ..................................... 104

4 Ten years later: Gated housing development in Sofia and Kiev............................ 111

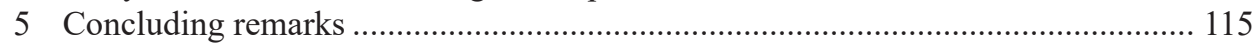

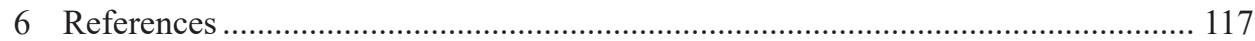

\section{Summary}

Thirty years after the fall of the Berlin wall in 1989 it is time to start a broader reflection on one of the most debated types of housing in Eastern European urban studies. Gated housing was almost unknown in the 1990s but started spreading rapidly at the end of the 2000s in different Eastern European and Post-Soviet countries. However, the 2008-2009 global financial crisis led to a sharp decrease in housing construction in general and of gated communities in particular. In recent years, housing construction as well as housing prices have increased again. Gated communities are part of this recovery.

Instead of providing insights from a certain period of boom or crisis, this paper looks at three decades of housing production in general and gated communities in particular. It tries to uncover the institutional and economic background of housing development

\footnotetext{
* Ass.-Prof. Dr. Christian Smigiel, Working Group Social Geography, Department of Geography and Geology, University of Salzburg, Hellbrunner Straße 34, A-5020 Salzburg; Prof. Dr. Kostyantyn Mezentsev and Assoc.-Prof. Dr. Nataliia Provotar, both Department of Economic and Social Geography, Taras Shevchenko National University of Kyiv, 64/13, Volodymyrska Street, UA-01601 Kiev [Kyiv], Ukraine. - Emails: christian. smigiel@sbg.ac.at; mezentsev@knu.ua; provotarnat@ukr.net.
} 
over the last 30 years. Moreover, it relates these developments to two (South)-Eastern European capital cities (Sofia and Kiev [Kyiv]) and their pathways of housing and gated community production. We focus on politico-economic and socio-spatial relationalities in these two different context conditions and scrutinise why and how gated communities emerged as well as how supply and demand changed over time. Both cases represent rather peripheral, capitalist economies concerning their national background. However, both cases are capital cities, which absorb the majority of capital investment. The polarisation and concentration of political and economic power structures lead us to discuss different actor-constellations regarding this on-going flight to privatopia, reflecting on the role of urban planning as well as glocal housing markets. Last but not least, this paper shows that gated communities are "urban assemblages" of wider processes of peripherialisation.

Keywords: Housing production, gated housing, gated community, crisis, glocalised housing, housing policy, Sofia, Kiev [Kyiv], peripheralisation

\section{Zusammenfassung}

\section{Von der Ausnahme zur Regel? Eine Analyse Zur Entwicklung von „GATed Communities“ in Sofia Und Kiew SeIt 1989}

Drei Jahrzehnte nach dem Fall der Berliner Mauer wird im vorliegenden Beitrag der Versuch einer umfassenden Analyse eines intensiv diskutierten Wohntyps unternommen. Nahezu unbekannt in der 1990er Jahren, erlebten viele Städte des östlichen Europa sowie der postsowjetische Raum einen regelrechten Boom an Gated Communities in den 2000 er Jahren. Dieses enorme Wachstum von unterschiedlichen Formen geschlossenen und bewachten Wohnens kam jedoch durch die globale Wirtschafts- und Finanzkrise von 2008 zum Erliegen. In den letzten Jahren hat die Wohnbautätigkeit insgesamt wieder zugenommen. Gated Communities sind Teil dieser Entwicklung.

Die Autoren begeben sich in diesem Beitrag auf eine Zeitreise durch drei Jahrzehnte Wohnpolitik und drei Jahrzehnte ,, Gated Community“-Produktion. Hierbei gehen wir vor allem den institutionellen und ökonomischen Hintergründen dieser Entwicklung am Beispiel von zwei (süd)osteuropäischen Hauptstädten (Sofia und Kiew) nach. Wir fokussieren uns ferner auf politökonomische und sozialräumliche Rahmenbedingungen in diesen zwei unterschiedlichen Städten und untersuchen, wie und warum sich Gated Communities entwickelt und im Lauf der Zeit verändert haben. Sofia und Kiew können als periphere kapitalistische Immobilienmärkte bezeichnet werden. Gleichzeitig sind sie Hauptstädte, die einen Großteil der Investitionen im Immobiliensektor in ihren Staaten verzeichnen. Dies bedingt eine Polarisierung sozialräumlicher Strukturen, die wiederum durch spezifische Macht- und Kräfteverhältnisse (glokale Immobilienwirtschaft, Stadtplanung und Stadtpolitik) hervorgerufen und verstärkt werden. Zu guter Letzt befasst sich der Beitrag mit der Frage, inwiefern Gated Communities in Peripherisierungsprozesse eingebettet sind.

Schlagwörter: „, Gated Communities“, Wohnpolitik, Stadtplanung, Sofia, Kiew, Glokalisierung, Peripherisierung 


\section{Introduction}

Thirty years after the fall of the Berlin wall in 1989 it is time to start a broader reflection on one of the most debated types of housing in Eastern European urban studies. When gated housing was booming at the end of the 2000s in different Eastern European and Post-Soviet countries, many single case studies emerged (e.g. MAKHrova 2007; SMIGiel 2009; PolansKa 2010; Hirt 2012; GĄDECKi 2013; Brade et. al 2014, Kovács and HEGEDÜs 2014). In particular larger agglomerations saw a dramatic increase in diverse forms of gated and guarded neighbourhoods (gated communities). This proliferation has been attributed to a lack of planning regulations, a mistrust of public institutions and insecurity (HIRT and PETROVIC 2011), socio-spatial segregation and fragmentation (GĄDECKI 2013; KovÁcs and HeGEDÜs 2014), to different practices of neoliberal urbanisation (SMIGIEL 2016) and sometimes even to a particular history of fragmentation and control (LENTZ 2006).

However, the 2008-2009 global financial crisis led to a sharp decrease in housing construction in general and of gated communities in particular. In recent years, housing construction as well as housing prices have increased again. Gated communities are part of this recovery.

Instead of providing insights from a certain period of boom or crisis, this paper looks at three decades of housing production in general and gated communities in particular. It tries to uncover the institutional and economic background of housing development over the last 30 years. Moreover, it relates these developments to two (South-)Eastern European capital cities (Sofia and Kiev [Kyiv]) and their pathways of housing and gated community production. ${ }^{1)}$ We focus on politico-economic and socio-spatial relationalities in these two different context conditions and scrutinise why and how gated communities emerged as well as how supply and demand changed over time.2)

There are certain differences between both cases as Sofia represents the housing market of a capital city of a new EU member state, while Kiev portrays a Post-Soviet capital city housing market of a new national state. However, both cases represent rather peripheral, capitalist economies concerning their national background as well as they are both capital cities which absorb the majority of capital investment. The production of gated communities is closely connected to the general socio-economic development of societies and cities in South-Eastern European countries (SEE) and Post-Soviet countries. This concentration of political and economic power structures leads us to discuss different actor-constellations regarding this on-going flight to privatopia, reflecting on the role of urban planning as well as glocal housing markets.

\footnotetext{
1) We decided to compare gated housing in Sofia and Kiev as both contexts capture the variety and ruptures from post-socialist to peripheral capitalist urban development in (South-)Eastern Europe.

2) Although, we have tried to provide comparable data sets for Sofia and Kiev, there are several topics where comparable data are not available due to different methodologies.
} 


\section{The framework for gated housing in (South-)Eastern Europe}

The following chapters provide an overview concerning the main parameters that have shaped the production of these segregated urban landscapes. First, we notice an uneven production of gated communities. This unevenness refers to politico-institutional circumstances that provide the framework for this type of housing. It also refers to the spatial setting where they occurred as well as it is highlighting the very nature of housing production in peripheral capitalist economies in Eastern Europe that have all undergone a transformation from variegated state-socialist societies to variegated forms of capitalism. Second, Sofia and Kiev have experienced short periods of housing boom (in the early 2000s) and a housing crisis (in the 1990s and shortly after the 2008 global financial crisis) that portray unevenness and inequality. Third, both national (Bulgaria and Ukraine) and local contexts display several differences that are conditioned by moments of (economic and political) crisis as well general economic and geopolitical parameters.

\subsection{Socio-economic transformations}

Eastern European economies (from Central Europe to Post-Soviet states) changed substantially in the 1990s as these societies shifted from a state-socialist to a capitalist system (Stiglitz 2002; StenNing et al. 2010). Austerity politics and a reduction in public spending were the cornerstones of post-socialist transformation in the first two decades after 1989 (MRI 2017, p. 11; MATZNETTER and MundT 2012). This had a profound impact on societies and led to a decade of crisis since privatisation of land, companies and prices created serious shocks and a dysfunctional, polarised system resulting in very few winners (mostly former national/local elites) and large numbers of unemployed and impoverished people (Stiglitz 2002; Smith 2007).

In Bulgaria, industrial production decreased by 60 percent, GDP by 34 percent and real income collapsed by 70 percent in the late 1990s compared to 1989 (EBRD 1999, p. 205). This led to a severe financial and economic breakdown at the end of 1996. Therefore, Bulgaria and its international lenders decided to introduce a currency board in 1997. This meant a fundamental change for the Bulgarian economy. It created a fixed exchange rate with the Deutsche Mark/Euro which has led to low rates of inflation on one side. On the other side, prices of Bulgarian products increased considerably, and a new accumulation regime emerged consisting of wage and social dumping (Ivanova 2009, p. 171). ${ }^{3)}$ A second pillar of this new regime is the orientation towards foreign capital investment (FDI). In fact, foreign direct investment amounted for almost 30 percent of Bulgaria's GDP in the mid-2000s. Moreover, investment in real estate has become a major source of revenue (especially until 2008) supported by national and local governments and different legal acts. Up to 30 percent of the annual FDI flow was investment in real estate (SMIGIEL 2016, p. 88). In terms of spatial distribution, Sofia has been the core of investment where more than

\footnotetext{
3) Economic and fiscal austerity policies have been another result of the currency board that obliges Bulgarian governments and the Bulgarian National Bank to execute strict budgetary discipline.
} 
50 percent of the foreign direct investments have been taking place since the early 2000 s. Gated communities were part of this investment scheme, as the paper will outline later.

In Ukraine, GDP shrank by even 85 percent and industrial production by 70 percent between 1990 and 1997 (EBRD 1999, p. 280). The main problems were caused by the formation of the nation state, transition to a capitalist economy, followed by changes in ownership models, and by the breakdown of traditional economic relations (MEZENTSEV et al. 2015). Market reforms and liberalisation of foreign economic activity happened only in the 2000s. FDI into Ukraine's economy since the mid-1990s has been associated mainly with short-term projects. Significant growth in the 2000s was derived essentially from the privatisation of state-owned industrial enterprises and mergers or acquisitions in the banking sector (REDZIUK 2009). The peculiarity of FDI is that some of it was of Ukrainian origin, and also aimed at acquiring existing (previously built) enterprises, their expansion, reconstruction and modernisation (PEREVERZIEVA 2016). They are characterised by a significant concentration in Kiev (40.3 percent in 2010 and 52.8 percent in 2019). Meanwhile, the impact of foreign remittances is significant and is recently surpassing the amount of FDI. The volume of foreign remittances (from Ukrainian labour migrants) through the international payment system is increasing recently, reaching 12 billion USD in 2019.

Moreover, social policies (pension system, education, unemployment and health insurance) suffered chronic funding shortages in both countries. Within this setting, housing provision as well as housing regimes also changed. Mass privatisation of housing units produced new strata of homeowners on the one hand, ${ }^{4)}$ while the withdrawal of the state led to a decay of whole neighbourhoods, facades, public places and parks on the other.

\subsection{Housing policies}

Since 1989 housing policies in South-Eastern European countries went through different periods, which, however, are framed by a common neoliberal set of ideas and strategies that have been advocated by a heterogeneous mix of powerful actors and discourses. It includes path-dependent power structures of old and new business elites, national and urban policymakers, local bureaucracy as well as global consultancies. One of the key issues was the uncontested introduction of property markets in Sofia and Kiev as well as in all other former state-socialist cities. Ownership of land and real estate and the subsequent extraction of rent have changed cities in South-Eastern European cities fundamentally as well as they are one of the socio-economic pillars of housing production.

The 1990s saw an overall dissolution of housing subsidies and services that followed a housing model promoted by international institutions, such as the World Bank, International Monetary Fund, and EU institutions. Global policy advisory groups produced two

\footnotetext{
4) According to recent Eurostat statistics, Bulgaria has a homeowner rate of 84 percent. Only 2-3 percent are owners with mortgages or loans (https://appsso.eurostat.ec.europa.eu/nui/show.do?dataset=ilc_lvh 02\&lang =en; retrieved May 12, 2020). In Ukraine, the share of homeownership exceeds even 90 percent (https://www. cedos.org.ua/en/articles/derzhavna-zhytlova-polityka-v-ukraini-suchasnyi-stan-ta-perspektyvy-reformuvannia; retrieved August 16, 2020).
} 
policy papers - Housing Reform in Socialist Economies (1990), Enabling the Markets to Work (1993) - that described how housing markets and urban policy had to be restructured, privatised and deregulated. One can read that housing reforms are "indispensable to the success of the overall economic reform" (RENAUD 1990, p. 56), and "that governments are advised to abandon their earlier role as producers of housing" (World Bank 1993, p. 1). Moreover, privatisation of housing production should go hand in hand with the overall privatisation of public sector enterprises.

This indicates that housing was discursively constructed as an almost exclusive subsector of economic policy and as part of an overall economic restructuring that needs to be organised in order to create investment opportunities for different forms of surplus capital. Politically, it was not implemented as a linear policy transfer. In contrast, these global policy models were mobilised and adopted by national and local policymakers, but still became a kind of blueprint in many South-Eastern European countries and cities in the 1990s (MRI 2017, p. 19). Consequently, South-Eastern European countries saw a specific adaptation of the proposed cut of state subsidies for housing, an abrupt stop of public housing construction, dissolution of state-owned construction companies and uncoordinated privatisation of the housing market (TosICS and HEGEDÜs 2003). Since coherent housing policies were absent, social-spatial inequality increased as many countries experienced a severe economic downturn in the first decade of transformation. Increasing prices for energy, water as well as living costs resulted in unprecedented levels of poverty. Social housing programmes barely existed (MRI 2017).

In the early $2000 \mathrm{~s}$, national housing policies or specialised housing programmes started to be introduced in a number of Eastern European countries again. However, they usually lack a coherent long-term vision of how to promote sustainable forms of housing and are usually underfinanced. Institutionally, decentralisation of political power from the central to the local level led to increasing competition among local municipalities regarding all sorts of revenues. Usually, capital cities and their suburban areas benefitted most from the increasing levels of (foreign direct) investment in housing that started to arise in the 2000s.

\section{Sofia}

Sofia's housing market followed the outlined mix of privatisation and reduced or abolished housing subsidies. Dilapidation of large parts of the housing stock is one of the most visible outcomes (STANILOV and HIRT 2014) as coherent and adequate long-term housing policies were missing as well. Additionally, social housing construction or programmes for public social housing have not been introduced (DANDOLOvA 2014). Furthermore, agricultural lands in the outskirts of Sofia underwent a large-scale privatisation and restitution process.

"The biggest problem is that there is no housing policy neither at national nor municipal level. Furthermore, there are no efforts to supply the city with social housing at all. Yes, there is a large number of residential units which cover the needs of many inhabitants. However, when you look at quality and size you see that there are problems. Of course, there is a need, but obviously our society is not mature enough responding to it." (Urban planner, City of Sofia, interviewed in 2012) 
Homeownership is the dominant form of housing as in many Southern and South-Eastern European cities. ${ }^{5)}$ The rate of homeownership in Sofia increased from 70 percent at the end of the 1980s to more than 90 percent in the early 1990s (BoGDANOv 2006). The rental market is still of minor importance even though levels have started to increase up to 10-15 percent of the market share in 2011 (MRI 2017). Hence, residential mobility has remained at low levels due to a missing public or private rental sector. Housing affordability has been another crucial problem especially in capital cities in general.

Affordability measures the intersection between cost of housing and purchasing power. South-Eastern European capitals such as Sofia and Kiev had the worst housing affordability among Eastern European capitals before the global financial crisis of 2008 due to high house prices and low average incomes. Households with an average income needed to save for almost 50 years (Sofia) or even 74 years (Kiev) to buy a standard 60 sqm flat in 2007 (REAS 2008, p. 13). Even though prices had dropped by more than 30 percent during the global financial crisis in 2008 they have recently reached pre-crisis levels in Sofia. Only the highest income deciles are able to pay market rents or to purchase a twoor-three-room apartment according to a recent housing report (World Bank 2017, p. 120). More than a third of young adults are unable to afford a house and continue to live with their parents in the Bulgarian capital.

\section{Kiev [Kyiv]}

The new housing policy in Ukraine started in 1992 with the adoption of the Law "On privatisation of state housing". Mass free housing privatisation in Ukraine has somewhat absorbed the shock of market transformations, but at the same time reduced the housing stock in public ownership, which led to housing commodification and fixed the inequalities that existed at the time of privatisation (FEDORIV and Lomonosova 2019). Housing has become the most valued asset in a household's budget (ibid.). Further steps were related to the search for ways to provide legislative support for housing purchase, when in the mid-1990s a number of legislative acts were adopted to attract additional funds for housing construction (including household resources) and to create an effective housing market.

The housing market in Ukraine is characterised by high homeownership rates. According to the State Statistics Service, only 1 percent of urban housing in Ukraine is publicly owned. The share of rented housing is underreported, especially in Kiev, as the rental market remains very informal in Ukraine (LIASHEVA 2018).

The right to housing in Ukraine is guaranteed by the Constitution, so the state must assist those citizens who are unable to solve their housing problems themselves. In this regard, Ukraine retains elements of the socialist system - social housing and registered waiting lists, which were later supplemented by affordable housing programs. The Soviet legacy influences not just how the term social housing is understood, but also the public's expectations, in particular, that the (paternalistic) state is obliged to provide free housing which, in conformity with the post-Soviet context, could eventually be privatised (ZAPATRINA 2012). As part of measures to overcome the global financial crisis, the Law "On

\footnotetext{
5) https://appsso.eurostat.ec.europa.eu/nui/submitViewTableAction.do (retrieved May 7, 2020).
} 
Preventing the Impact of the Global Financial Crisis on the Development of the Construction Industry and Housing" was adopted in 2009, introducing an additional concept of affordable housing. Unlike social housing, the latter is provided by the state as aid to those who have insufficient resources to purchase housing.

Housing affordability is a critical issue for many households in Ukraine. For 80 percent of the population, the possibility of refurbishing their homes or improving their living conditions remains remote (ZAPATRINA 2012). At the same time, there is a "paradox of the housing market" (VERTYL 2016) meaning that quite a number of households have other sources of funding including some non-transparency in the declaration of real income that they are able to spend for housing.

\subsection{Housing production and housing finance}

Housing production collapsed in the 1990s since former building companies were dismantled. The former system of state-financed housing was abolished. Mortgage systems barely existed (STANILOV and HiRT 2014). Housing finance collapsed at the same time as foreign capital investment was low and private households struggled with economic and institutional instability. Therefore, up to the mid-2000s only 30-35 percent of the inhabitants in Bulgaria and Romania had a bank account compared to 98 percent in the EU-15 or 70 percent in Poland and Hungary (REAS 2008). Cash payment was the most prevalent form of housing finance (PóSFAI 2018).

From 2000 onwards, most Eastern European countries experienced a period of economic growth that led to the formation of (small) young urban upper-middle class mostly in capital cities as recent figures for Sofia and Kiev indicate. ${ }^{6}$ EU enlargement in 2004 and 2007 opened the way for a large wave of investment by Western financial institutions in SEE countries, which enlarged their market share and created high profits and new spatio-temporal fixes (PóSFAI 2018, p. 51). Additionally, liberalised capital markets, free movement of capital, low interest rates and a vast majority of foreign-owned banks provided the economic and institutional framework for a substantial increase in housing construction and housing prices as Figure 1 indicates for Bulgaria. Different globally operating real estate funds and individual investors entered the Central-East European (CEE) and South-East European (SEE) market triggered by an access to easy money and promising high rates of return. Mortgage lending systems started to be introduced as well.

\footnotetext{
6) While Sofia gained only a small percentage of new inhabitants in the early 2000 s due to a strong wave of emigration from Bulgaria to Western Europe and low birth rates in general (MLADENOv et al. 2008), the situation has changed in recent years. Internal migration of the age group 15-30 is particularly driving the increase of population numbers in Sofia since 2010 (National Statistical Institute 2020). In 2000-2009, Kiev's population increased by 8 percent (219.2 thousand people) owing to newcomers. In the next decade such an upward trend remained but slowed down to 5 percent (140.3 thousand people) caused by the growing outflow to Central and Western Europe. Despite this slight reduction, Kiev and its suburbs ranked first among all regions of Ukraine by net migration. Just under a half of the registered immigrants was aged 15-29 (in 2019: 46.2 percent, in 2018: 47.8 percent, according to the Main Statistical Office in Kiev). Moreover, while roughly one-third of Kiev's adult residents are officially registered outside the city or its suburbs, among young people this portion is 5-7 percent higher (SLOBODIAN and Fitisova 2018).
} 
However, a high share of "foreign currency dominated mortgage loans strongly increased the vulnerability" (MRI 2017, p. 28) to external shocks of many households in these countries as happened in 2008. Moreover, the peripheral position of SEE economies and housing markets made CEE and SEE countries vulnerable in a structural way. In fact, capital flows were cut immediately and rechannelled to Western markets in 2008/09. Globally operating banks closed their SEE branches as the global financial crisis intensified.

While the 2000s saw a housing boom, the crisis of 2008/09 paralysed the housing sector abruptly as many projects remained unfinished and housing production stopped as chapter 4 will demonstrate taking the example of Sofia's gated communities. However, the ongoing financialisation of housing had been visible even before the crisis as many apartments were sold en-bloc to international investors (SMIGIEL 2016). This tendency might have changed slightly but buying an apartment for investment has become a widespread trend. Statistics for Sofia show that from 2013 to 2018 25-40 percent of apartments were purchased for investment (Colliers International 2018).

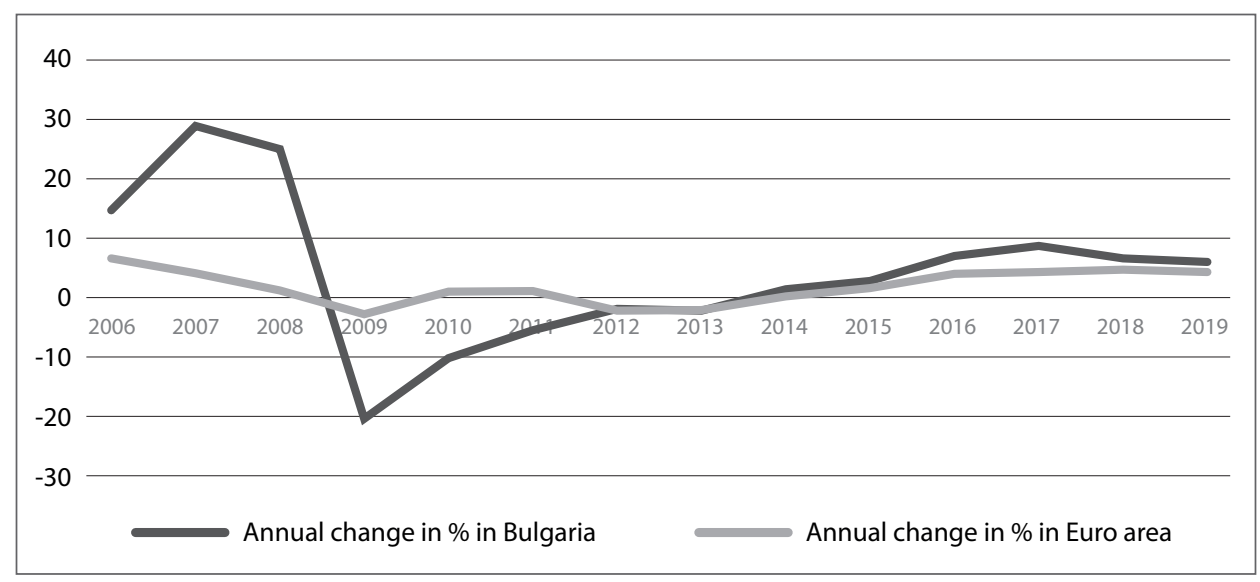

Source: Data source: Eurostat 2020 (cf. https://ec.europa.eu/eurostat/web/housing-price-statistics/ visualisations; graphic: own design

Figure 1: Annual change of housing prices in Bulgaria and in the Euro area 2006-2019

Since $1991 \mathrm{Kiev}$ has undergone a rapid transition from a large but internationally unimportant Soviet city to its current status as the capital of one of the largest countries in Eastern Europe, becoming a magnet for all Ukraine, which significantly increased the demand for new housing (KYI and PAL 2002). New housing construction decreased significantly in Ukraine in the 1990s compared to the 1980s similar to the situation in Bulgaria and Sofia. ${ }^{7)}$ However, new housing construction never ceased, not even during the economic crises of 2008 and 2014 which only slowed the relative pace of growth (LIASHEVA 2018). In the

\footnotetext{
7) Numbers of new-built housing units in Sofia dropped from more than 16.000 housing units at the end of $1980 \mathrm{~s}$ to less than 1,000 constructed new housing units in the mid-1990s (VESSELINOV 2004).
} 
1990s, due to the lack of new housing, there was a significant unmet demand (Sistema ipotechnogo kredytovaniia 2004). A significant excess of demand over supply stimulated price increases (BIBIK and DRIL 2017). The dominant position in the housing market of Kiev was occupied by the state holding company "Kyivmiskbud". The influence of the banking system was insignificant. Foreign capital was virtually absent. ${ }^{8}$

The situation changed significantly from the early 2000s as mortgage lending legislation was introduced in Ukraine. As a result, by 2008 new housing construction was growing significantly (Figure 2). Mortgages to households increased to 15 percent of the country's GDP. The number of developers and the role of Ukrainian banks significantly increased, and powerful coalitions of public and private actors have emerged. Corporate relationships between commercial banks and housing construction companies sped up the growth of mortgage lending (PyLYPETS and MaTYASH 2006). A number of foreign banks entered Ukraine as well. Having low reserves domestic banks started borrowing on the international market and providing loans in Ukraine at inflated interest rates (LIASHEVA 2018). The difference between the domestic and international financial market provided liquidity to the Ukrainian real estate market (ibid.). This in turn led to the dominance of mortgage loans in dollars (60-80 percent of all mortgage loans in the 2000s). More than two-thirds of the market was controlled by large banks, which had strong corporate ties with developers (USPALENKO and TYTARENKo 2016).

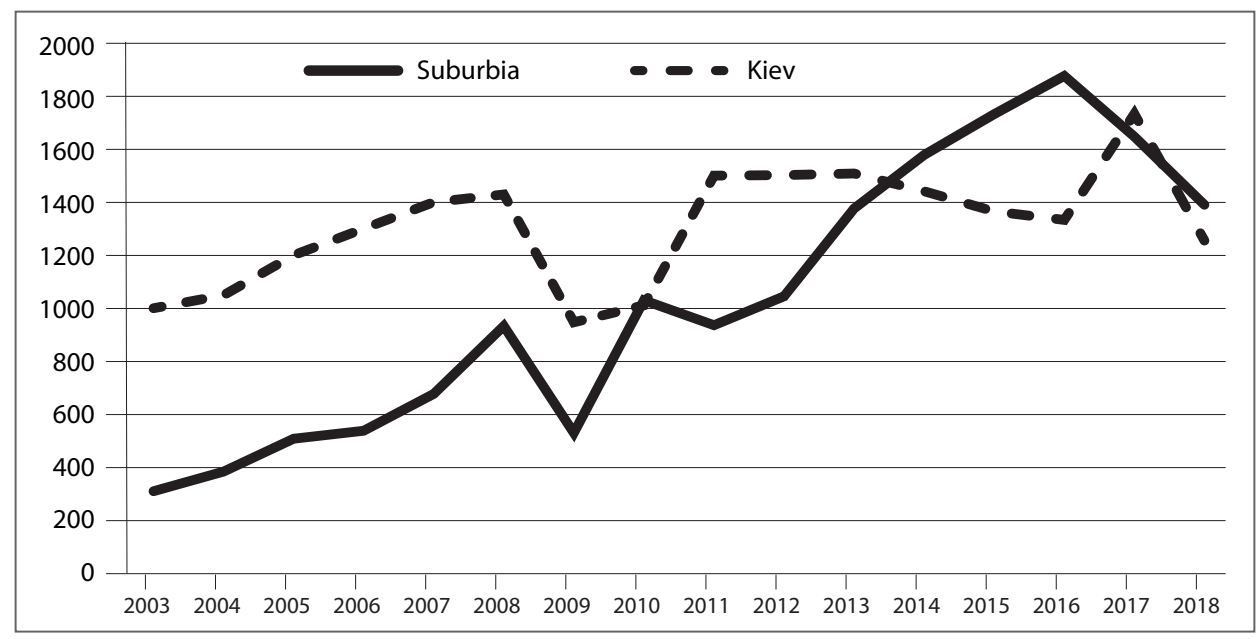

Source: Data source: Statistical service of Ukraine; graphic: own design

Figure 2: Dynamic of new housing construction in Kiev and suburbia 2003-2018, in $1000 \mathrm{~m}^{2}$

An important factor was the commodification of land (LiASHEVA 2018), which led to the emergence of non-transparent schemes for the provision of land and situational coalitions between the city authorities and developers.

\footnotetext{
8) As already noted above housing construction in Sofia was dominated by both larger Bulgarian and foreign developers since Bulgarian property markets were earlier exposed to international investors.
} 
In 2008-2009, the global financial crisis led to a slowdown in new construction, including new gated communities, due to a downturn of effective demand, a significant decrease in mortgage lending, and rising interest rates on loans. The crisis has exposed growing demand and inflated housing prices, as well as banks' wrong policies in encouraging the growth of mortgage lending. The "speculative bubble burst" (ATANAsov 2010), or rather, the "price bubble" did not burst at all, but only slightly reduced (BIBIK and DRIL 2017).

In 2009, out of more than 200 unfinished and planned projects of "cottage villages" in Kiev's suburbs less than 10 were built, and prices decreased by about a third (Figure 3). The fall in housing estate prices in Kiev was more significant, but they recovered faster and began to rise. In the post-crisis period, dollar prices did not reach the peak level of 2007-2008.

If in the pre-crisis period more than 20 percent of new housing was concentrated in Kiev, after the crisis the share increased to 30 percent and higher. Kiev was the undisputed leader in mortgage lending (over 35 percent).

The impact of the financial crisis in the suburban area was manifested in different ways: in some areas in 2009 new housing fell by 40-60 percent, in others the reduction started only in 2010, and some areas were not affected in 2009. The latter can be explained by those who were investing private savings in the completion of the most financially sound projects, concentrated in certain areas of prestigious estates near Kiev.

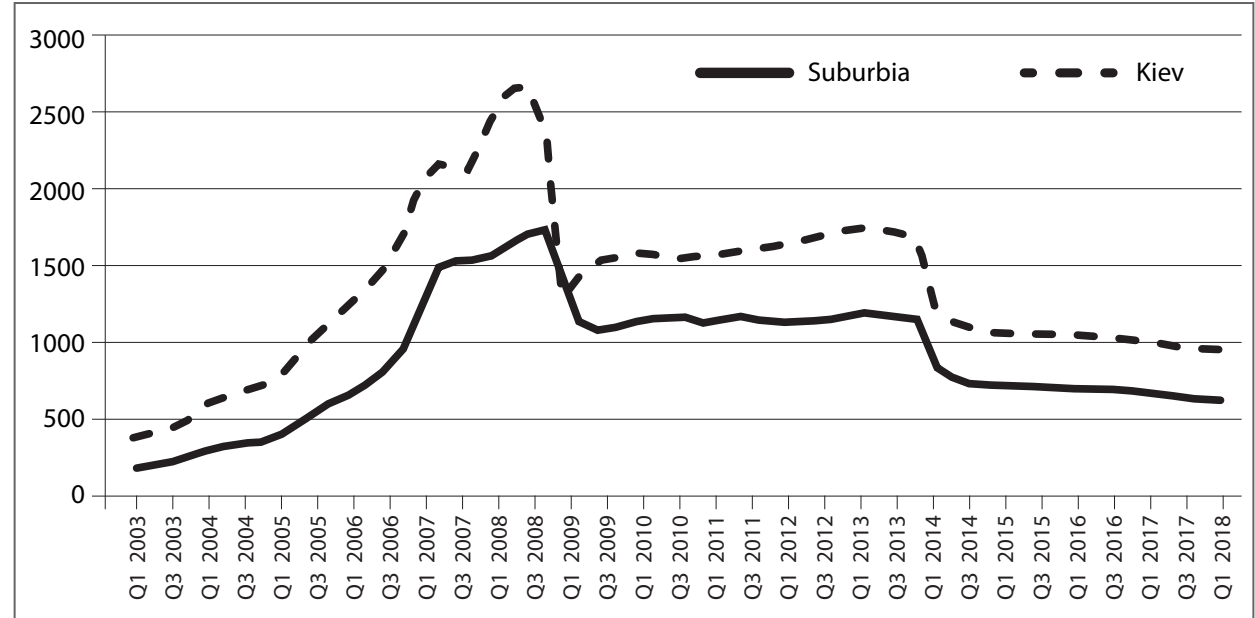

Source: Data source: SV-Development Consulting Company (cf. http://www.svdevelopment.com/ ua/web/house_costs/, in Ukranian); graphic: own design

Figure 3: Dynamics of average quarterly prices for houses in the suburbs and new apartments in Kiev 2003-2018 (US dollars per $\mathrm{m}^{2}$ )

Another crisis was the result of the war in Eastern Ukraine and the subsequent economic crisis in 2014-2015. Given the reduction in effective demand, oversupply of housing led to lower prices. In 2014-2015, new housing construction in Kiev also decreased. Some 
of the frozen (postponed) housing construction was completed in 2017. In the suburbs, new construction grew until 2016. The decline in housing construction is also caused by declining demand for large suburban houses and large apartments in the city.

Further growth of new construction has a completely different character. The growing demand is explained by the mass closure of banks, declining trust in the banking system, as well as a significant decline in the national currency, as this has led to a situation where real estate has become the primary way to secure savings (LIASHEVA 2018). At the same time, the demand for elite housing remained quite low.

According to the National Bank of Ukraine, the state of mortgage lending is characterised by a number of problems and hinders the development of the new housing market. 92 percent of new mortgage loans are provided by only a third of banks, and the volume of mortgage loans to households fell to less than five percent of the GDP (Natsionalnyi Bank Ukrayiny 2020). The key problems are related to the non-transparency of the mortgage lending and primary housing markets, high interest rates, the lack of effective mechanisms to protect the rights of household investors, the untimely commissioning of housing, etc. (ibid.). New mortgage loans are used mainly on the second-hand housing market.

\subsection{Urban planning}

Urban development in general and housing in particular are usually based on long-term, large-scale master plans on one side and small-scale building guidelines and regulations on the other. The cases Sofia and Kiev demonstrate that visionary master plans had been missing for most parts of the so-called transformation period in both cities. Therefore, housing production and urban development until the 2000s were approved based on outdated documents from the 1960s or 1970s. Additionally, a lack of institutional coordination between urban planning authorities from the capital cities Sofia and Kiev with their suburban counterparts led to uncoordinated and uncontrolled urban sprawl.

\section{Sofia}

Urban planning in the last three decades might have had heterogeneous agencies but all plans and programmes have followed a particular entrepreneurial version of city planning. It started with a lack of updated official planning documents as the city of Sofia introduced the first post-1989 master plan in 2007/2009 (SMIGIEL 2014, p. 183). ${ }^{9)}$ Consequently, land use changes, building and planning permissions or any other kind of judicial step was done without a long-term political vision of urban development for almost two decades of transformation which resulted in fragmented decision-making mostly executed by overstrained district-level authorities. Private investors took advantage of this situation. Additionally, city authorities were in favour of large-scale investors and facilitated any kind of investment that generated tax revenues and created public infrastructure (STANILOV and HIRT

\footnotetext{
9) The vacuum was filled by external policy advice (World Bank 2003: Sofia City Strategy), the City Renovation Initiative (UNDP) and papers that had a huge impact on Sofia's urban development.
} 
2014, p. 181). In 2004, a special law for large-scale investors was introduced that provided quick project approval procedures as well as public subsidies (see chapter 3.1.3). Consequently, Sofia experienced a mushrooming of shopping centres by large-scale investors in a very short period of time (STANILOV and HiRT 2014).

"There are rules. The problem is that in many cases the rules are not obeyed or strictly followed. So that is the problem. [...] Moreover, most of the development was done before 2007 and 2008. That means before we prepared the new master plan. The master plan is good one. It is a precise urban planning document in my point of view. However, it was introduced too late. [...] And now we do not demolish the existing buildings anymore. By law we have the authority and power to demolish something that has been constructed illegally or in an irregular way. But in reality it is rarely done." (Urban planner, City of Sofia, Sofproject)

Moreover, city planners actually embraced the idea of an entrepreneurial city. Suburban sprawl, for example, was considered as catching up with Western paths of modernisation. Beyond that public intervention was seen as a characteristic of the socialist past that had proved to be dysfunctional as documents and Sofia's leading urban planners have put it (HIRT 2007, p. 773). However, the idea of a polycentric city that expands its boundaries was only loosely controlled and not sufficiently accompanied by urban planning rules.

Summing up, glocal relationalities led to a heterogeneous mixture of an adoption of urban visions promoted by external experts, missing or imprecise planning documents and dozens of investor-led "revitalization or regeneration" projects that all have provided conditions for a commodification of urban space.

\section{Kiev [Kyiv]}

In the early 1990s Soviet legislation and building codes were used in Ukraine. Although the Law "On Fundamentals of Urban Development" and state building codes were adopted in 1992, the development of cities, including Kiev, was chaotic, with the absence of proper state control over new construction, in violation of legislation and building codes.

National legislation was developed in the 2000s with the adoption of the Laws of Ukraine "On Spatial Planning and Development" (2000) and "On the General Scheme for Spatial Planning of Ukraine" (2002). Based on them, a range of new master plans and detailed plans were developed. In particular, in 2002 a new "Kyiv Master Plan" to 2020 was adopted, which to some extent contributed to the improvement of land relations and new construction. However, in the 2000s, most Ukrainian cities did not have up-to-date urban planning documentation; their master plans were developed in the 1970-1980s, and in many cases proved unusable. Therefore, the Law "On Regulation of Urban Development" (2011) has played an important role, requiring the development, updating and approval of master plans, zoning plans and detailed plans of the territory. Moreover, they must be agreed with local communities through public hearings. In the absence of a zoning or detailed plan, the provision of land plots from state or communal property for urban planning purposes is prohibited. 
However, Ukraine still has a rather non-transparent system for obtaining permits for construction and commissioning of housing. In many cases, current building codes are ignored. A number of projects are being implemented despite public protests and court decisions. At the beginning of 2020, the main provisions of the new Kiev's Master Plan until 2040 were published, but the public discussion was postponed to the period after the quarantine caused by the spread of COVID-19.

\section{Until 2008: The story of gated housing in Sofia and Kiev}

The story of gated and guarded housing complexes in Sofia and Kiev until the global economic crisis of 2008 can be told in different ways. One possibility is to use an actor-oriented storyline, which divides and differentiates the main actors in terms of promotion, investment, construction and management similar to Peter AMBROSE's housing provision chain (1991). Another way would be to write a "little" cultural history of gated housing tracking different historical periods (e.g. the Ottoman and socialist ancestors) and compare them to current gated communities (Lentz 2006; Stanoeva 2010). A third option would be a sociological journey to different gated communities in order to uncover motives, rationale and everyday life. While a comprehensive discussion ${ }^{10)}$ of each of these options goes beyond the scope of this paper, we attempt to tell the story of gated housing complexes in Sofia and Kiev after 1989 by distinguishing three phases, their politico-economic circumstances and actors as well as socio-cultural characteristics. The main focus is put on highlighting relationalities and contradictions of each period.

\subsection{Sofia}

\subsubsection{The early period - "self-organised" gated communities}

As in many other cities in Eastern Europe, the proliferation of gated housing complexes in Sofia did not start immediately after 1989. Therefore, the first phase that lasted throughout the 1990s can be considered as a period in which the phenomenon of gated housing complexes barely existed both materially and as an image of segregation. In fact, there were only very few secluded neighbourhoods outside the city limits. However, it was a time when social polarisation took off. Bulgaria experienced a deep economic and social breakdown as outlined earlier. Due to increasing unemployment, reduction of subsidies and the dissolution of the social welfare state, almost every second inhabitant of Sofia experienced severe poverty. More than 40 percent lived below the poverty line in the mid1990s (RIEDEL 2003, p. 59).

Although housing functioned as a kind of safety net as 90 percent of Sofia's inhabitants lived in owner-occupied apartments, the pseudo-privatisation had created a vacuum concerning maintenance of all kinds of public space (green space, stairways, facades etc.).

\footnotetext{
${ }^{10)}$ For a detailed analysis of gated housing complexes in Sofia see HIRT (2012) or SMigiel (2016).
} 
Consequently, many housing estates started to decay due to the lack of interest of public authorities who had withdrawn from managing public space. Additionally, a large majority of individual owners were financially not capable of managing the burden of maintenance. Therefore, the social profile of neighbourhoods started to change slowly. However, even though an overall polarisation started rapidly to increase, segregation patterns did not change much as housing mobility and construction remained low until the early 2000s. State-owned building companies had been dissolved or privatised and transnational real estate investors were almost absent as the Bulgarian real estate market was as yet undiscovered.

In this setting the first, mainly small and "self-organised gated communities" (STOYANOV and FRANTZ 2006, p. 60) appeared at the end of 1990s. Close social as well as professional ties characterise these early gated communities. The social networks consisted of a heterogeneous mix of (former) politicians, state officials, local businesspeople and profiteers from privatisation. Investment and construction were done by the developers themselves or by parts of the network as the following citation by gated community developer shows.

"My father, who was born here, had the idea for a gated community when he was district mayor of Pančarevo for a short period after 1989 [Pančarevo, in the Southern District of Sofia where the gated community Mountain View Village is located; the authors]. It was essential for him to collect as much land as possible for the family. [...] And somehow he was able to collect a lot of land in a private way, because the biggest part of the territory was agricultural land which was publicly owned. He acquired it for a very low price. Other plots were bought for practically nothing from the restituted owners who were mostly peasants or the heirs offormer peasants. [...] Well, the whole community was financed by my father who passed away. We sold the majority of the houses but kept seven houses for living and renting. [...] We just sold most of the houses to our friends - never to anybody else. The rest of the houses still belong to my brother's company." (Manager and owner of the Gated Community "Mountain View Village").

As the citation indicates, inside knowledge concerning restitution of land and ownership structures played an important role in order to start the building of the complex. Additionally, many gated community developers bypassed urban planning rules and legislations as plots of gated communities were constructed on areas that had been declared for agricultural use only. The financing in most cases was almost exclusively done by personal capital and without loans or bank credits. While the initial economic motive cannot be reconstructed entirely and remains a vague mix of investing money and creating a new business, the social motive is a quest for segregation and seclusion. On the one hand all of these gated communities were constructed, at least partially, for personal use and on the other they did not use advertisement in order to promote the complex. In contrast, the owners selected the residents personally (SMIGIEL 2014, p. 186). Consequently, a group of affluent and well-connected families moved in accompanied by a few expatriates. 


\subsubsection{Consolidation of a trend-gated communities "made in Bulgaria"}

A "second generation" of gated communities started to spread in the early 2000s. Unlike the "first generation" these gated communities did not hide in peripheral areas. Although the majority of these newly built gated complexes are situated in the prestigious Southern districts of Sofia, the spatial pattern consists of suburban as well as inner-city gated communities. Moreover, the complexes were much larger (with more amenities) and usually designed for at least a few hundred residents. Concerning the main actors, Bulgarian entrepreneurs prevailed. However, the set of economic as well as socio-cultural incentives is quite different from the prior phase of gated community production. First, these gated communities were not produced or designed to function as personal enclaves. The prime goal of the developers was to invest in housing in order to solve over-accumulation as the following citations highlight.

"The investors are Bulgarian businessmen. They are a group of three people. They actually hired a manager or a company who is dealing with the complex instead of them, because this is their first and last complex. So they are not in the real estate business. But each of them made some money in Germany, Austria and Italy which they invested here. [...] I know that they have been discussing building something like that for about 10 years. Then they met this project manager and they thought it is the perfect time to start and they did it. They will never build any complex again." (Architect gated community "Silver City")

"We used to be the main producer and importer for sanitary products in Bulgaria from 1993-2001. In the best times our company used to hold 46 percent of the market. We used to have a 46 percent market share for such products especially for sanitary towels and baby diapers. And later on we kept the name "Maxi" as a brand name for the housing project. [...] But since my father had the idea to make something different in order to invest our money, we started buying land in 1998. The idea for such a project comes from the States where we used to live in the 1990s." (Owner and general manager gated community "Maxi Club Green City")

Although the individual background of the developers is variegated and ranges from food business and agriculture to sanitary products, the common economic motive was to shift capital from the primary to the secondary circuit of capital in order to fix capital flows spatially and temporally (HARVEY 2001).

Second, billboards, press articles and different kinds of advertisement disseminated the idea of gated and guarded housing complexes and created a public image. In fact, these advertisements shaped the public perception of gated communities as luxury and elite housing complexes "made in Bulgaria". Although reality proved to be slightly different and quite a number of residents complained about constructional shortcomings; average apartment prices were not affordable for even higher-income households (SMIGIEL 2016, p. 147). Therefore, the residents' structure usually consisted of expatriates and young Bulgarian upper-class households. However, in contrast to the promoted image of a gated 
community, the idea of community did not play an important role neither for the developers nor for the residents.

Last, but not least gated communities in general fit the idea of an entrepreneurial city described above. Therefore, urban policymakers as well as urban planners at the local and municipal scale welcomed the idea of powerful private developers that provide housing and urban infrastructure (STANILOV and HIRT 2014). Consequently, gated community developers were seen as major investors and actors of an urban transformation. The appreciation of gated communities did materialise in several subsidies by public authorities and a rather generous interpretation of building regulations.

\subsubsection{The new generation of gated communities - Gated housing as a product of financialised capitalism}

From the mid-2000s, Sofia experienced an enormous increase of foreign direct investment in real estate. Gated communities were part of this boom. Mainly globally operating real estate investors dominate this process. Attracted by special tax considerations and promising return assumptions these new types of financial actors have been the major force of gated community production in Sofia with a total volume of investment of more than one billion Euros. They constructed more than 80 percent of Sofia's 70-80 gated communities. However, the production of this "third generation of gated communities" is a complex as well as multiscalar process involving Real Estate Investment Trusts (REITs), Real Estate Private Equity Funds (REPEs), and other different financial institutions as well as (transnational, national and local) public authorities. This includes strategic alliances and partnerships including material relationalities, legal arrangements and symbolic alliances.

In terms of material relationalities globally operating real estate investors received state-funded subsidies in order to be able to complete their real estate projects. Moreover, the Sofia municipality started to build public bus stops for these private housing complexes. Besides material relationalities and legal arrangements one can find symbolic "alliances" like the "National Building of the Year-Award" - a prize founded by the Ministry of Infrastructure and Regional Development in cooperation with the Bulgarian construction industry and the national broadcasting service. Different gated communities have been awarded "Building of the Year". The ribbon-cutting opening ceremonies were done by the mayor of Sofia or even the prime minister of Bulgaria.

"We got a support from the state, because it [Residential Park Sofia; the authors] was considered as a priority project and we got around 5.5 million Euros. But we had to invest a lot! In a way it is a kind of public private partnership. But we have actually invested a lot of money in Business Park and Residential Park Sofia. So it is clearly a win-win situation for both sides. [...] Legally it is a complicated case. It was considered a priority of one of the ministries. And there is a special law of promotion of investment. And we got support through that programme. So the state supported investments and then it was transferred as a property to the municipality. Actually, after our case they changed the procedure and now the money is first 
transferred to the municipality and then to an investor." (General Manager of the gated community "Residential Park Sofia"). ${ }^{11)}$

"In terms of public private partnership, the Residential Park is quite a nice example, because this closed-type complex was allowed under the condition of improving the public infrastructure. Therefore, they received money in order to construct a part of the ring road. So this is a kind of public private partnership. A public private partnership is not defined by law or in some kind of strategy paper, but such major actors in construction or major developers are always asked to help the municipality which does not have enough resources for constructing a proper street network. But it is also in their interest to have functioning infrastructure." (Urban Planner "Sofprojekt, City of Sofia").

Contrary to their portrayed forerunners, these gated communities reflect a type of housing production that can be described as "globally produced estates" and "financialised landscapes". ${ }^{12)}$ This comprises different spatial scales. It embeds the local scale "Sofia" where the complex itself is situated as well as where the management companies and brokers are located. Moreover, there are regional headquarters of financial investors in different European cities as well as private equity funds registered in the British Virgin Islands or on London stock exchange.

Relationality concerns the complex network of different financial actors, too. The variety of actors involved range from private equity funds, financial institutions (e.g. Deutsche Bank, Raiffeisenbank, Piraeus Bank), holdings, fund managers up to newly established local institutions who are responsible for the daily business. This leads us to question why gated communities are organised in such a complex and interleaved manner.

Behind this complex setting we can find two general motifs that are linked to this particular inter-organisational structure. A major motif is a so-called reduction of liability. Bulgarian enterprises or legal actors own all gated communities. Before starting the construction process new "Bulgarian" enterprises are set up that function as exclusive owners. This means that they are economically and financially responsible for the operation, whereas the private equity fund or the holding company cannot be prosecuted even though they are providing the financial resources and gaining the profits. This leads

11) The following citation by the main architect of "Residential Park Sofia" includes another feature of politico-economic relationality and reflects the societal meaning of gated housing: "It was a long fight to get all permits for Residential Park. And this could only be achieved because of consistent lobbying. Our former general manager, who is now Bulgaria's Minister for regional development, public infrastructure and road construction, was a key figure. He did an amazing job for our project." The interview was conducted in March 2010. One year later, the mentioned former general manager of "Residential Park Sofia" was elected President of Bulgaria.

${ }^{12)}$ We define financialisation as a process which includes two structural components. First, this refers to the increased importance of the financial sector, its agents (banks, insurances, trusts, funds etc.) and practices (technologies, instruments), that have changed many economic sectors (including housing and real estate). Second, financialisation paraphrases a general tendency of financial capital that has become the major driver of capital accumulation which is aimed at increasing rates of return and volumes of financial capital (FERNANDEZ and AALBERS 2016; Zeller et al. 2018) 
us to a second major motif which Botzem and Dobusch (2012, p. 685) have called tax avoidance.

In fact, the vast majority of private equity funds that are functioning as holding companies are situated either in low-tax regions outside of Europe (e.g. British Virgin Islands, Cayman-Islands) or in special zones of low-taxation in the European union (e.g. the Netherlands, Cyprus). Tax avoidance in terms of gated communities means a splitting of revenues so that, due to a heterogeneous network of responsibilities, only a very limited amount of tax has to be paid in the "country of construction" (Bulgaria - executed by a Bulgarian fund) and in the country where the holding company is registered.

\subsection{Kiev [Kyiv]}

We can identify three versions/types of gated communities in Kiev that, since the early 1990s, reflect simultaneous rather than successive phases of separation and segregation: (i) "segregated wealth" in suburban areas, (ii) mass produced and mass consumed "cottage villages" as a style of life in suburbia, (iii) gated and guarded houses in the inner city. All these versions overlapped over time, were modified, strengthened or weakened, and coexisted before the financial crisis of 2008-2009.

\subsection{1 "Segregated wealth" in suburban areas: gated "Golden Gate" (from the 1990s)}

From the early 1990s, the construction of gated "cottage villages" started in the traditional summer houses ("dachas") and recreational areas in the river valleys of the Kiev suburbs. "Cottage village" is an unofficial name for fenced and guarded plots with a number of cottages (detached houses and later some other housing types, including townhouses). Such a housing estate has no definition in Ukrainian legislation and has not been regulated by law until now.

The development of "cottage villages" was characterised by non-transparent land allocations and non-transparency of the origin of developers' capital. The developers were mostly unknown limited liability companies, only a few of which later became large development companies, while most ceased to exist after the implementation of the construction projects.

The composition of those who lived in "cottage villages" was quite diverse - top government officials, successful businessmen of the 1990s, criminals, sometimes all interconnected, with complex intertwining interests and dependencies. But they were united by a desire to separate themselves from less affluent and successful people by the well-protected high fences of the gated community. Homeowners have invested their own capital without mortgage loans programmes. At the same time, they were investing in valuable real estate, highly liquid capital.

The development of "cottage villages" was quite obscure, without advertising, focusing on VIP-clients, "for the chosen ones". Even their names reflected wealth, elitism, had a symbolic meaning. For instance, the "Golden Gate" cottage village. On the one hand, this 
name emphasises gold as a measure of wealth, and on the other hand, the "Golden Gate" is an architectural symbol of Kiev, of the city centre and of the former princely power and prosperity.

Such "cottage villages" lacked architectural integrity, but had high-quality infrastructure - roads, their own social infrastructure facilities, elite estates behind high fences. An interesting metaphor for them is the "gate to a parallel world". Over time (in the 2000s), this version of the gated communities was built and sold mostly under the idea of a club quarter, a club town for people who have achieved a certain status.

"[...] the gate to a parallel world where there are no communal problems. In Koncha settlement, everything is thought out. Multilevel sewage system, artesian wells, the latest communications, excellent roads. At the entrance, a security post is equipped, in the territory there are surveillance towers, video cameras, and a patrol goes round the clock around the village. It has its own supermarkets, car dealership, restaurants, kindergartens and elementary schools, gyms, swimming pools, fitness centres, offices and even banks [...].“ (Kasianov 2010).

\subsubsection{Mass produced and mass consumed "cottage villages" as a style of life in suburbia (from the mid-2000s)}

The second type is gated settlements for mass consumers from the middle class. The construction was based on the principle of "offering the mass consumer what the rich men already have". This wave of urban expansion of green suburban spaces occurred in the mid-2000s and was associated with the development of new plots of land, especially along the river Dnieper and highways (Mezentsev et al. 2012). The boom in their sales was observed in 2004-2008. Such "cottage villages" were sold not so much as housing, but as entering into a certain way of life.

In many cases houses in "cottage villages" were bought as second homes, while the first one was in the city. Hence, we can talk about seasonal/weekend segregation, and sometimes about delayed (postponed) segregation, when housing was bought "for the future", for living there once people no longer needed to stay in the city (e.g. after retirement).

At the early stages, the developers were mostly unknown limited liability companies registered in Kiev. Later, well-known mass housing developers from Kiev as well as non-core companies (with other specialisation in the housing market or even from other spheres) entered the market in search of a quick payback and relatively easy profit. Almost exclusively Ukrainian capital was invested in the construction. At the same time, demand was stimulated by the development of various credit programmes and the entry of banks into the mortgage market. This version of gated communities is characterised by an architectural integrity, but at the same time worse infrastructure in comparison with the previous ones.

A range of "cottage villages" were built in "open fields", on agricultural land, without any permits. The construction was accompanied by powerful advertising of the suburban way of life. Their names also emphasised the environmental priorities - green, park, forest, garden (for example, "Green Grove", "Green City", "Forest Lake", "Mikhailovskyi Garden", etc.), although in reality environmental factors were not always taken into ac- 
count. They were constructed close to waste disposals, a thermal power station, even the Chernobyl zone. As a result, "cottage villages" had a number of disadvantages, ranging from the lack of postal addresses, official registration, paved roads, and shops. However, buying a house in a "cottage village" has become fashionable, and this was driven by the growing welfare of parts of Kiev's inhabitants. Over time, the distance of new "cottage villages" from Kiev was growing and the range of houses has expanded to include detached houses, townhouses, multifamily houses, etc.

"[...] in partnership with banks supporting mortgage programs in one or another project, developers did their 'great job'- they accustom wealthy Ukrainians to the culture of suburban life. In a 'package'with a house, a land plot and an attractive location, developers were selling the idea of a new lifestyle." (Commercial property 2009).

\subsubsection{Gated and guarded houses in the inner city - "small plots of land and densely packed affluent people" (from the 2000s)}

The third type of gated communities, which developed from the early 2000s, involved the reconstruction of old (historic) buildings and the construction of new ones in the Kiev inner city. It involved the realisation of the idea of so-called "club houses". In fact, only the old facades remained in the historic buildings, and everything else was refurbished. Such projects could be seen as a gated community development as they have their own social infrastructure (restaurants, swimming pools, spas, etc.) on the ground (and underground) floor and are, with access closed to outsiders, courtyards, video surveillance, etc.

\section{Ten years later: Gated housing development in Sofia and Kiev}

\subsection{Sofia}

English-speaking websites, billboards, short image films, cover stories in real estate magazines all promoted and popularised gated communities in Sofia as well as in many South-Eastern European (capital) cities, a trend that continued after the global financial crisis. By using such professional advertising and design, a certain imaginary was produced that relates this type of housing to a particular urban lifestyle of a so-called "European middle-class" (BODNÁR 2008, p. 140; PolANSKA 2010). Beyond lifestyle, aesthetics plays an important role as it serves as an element of class distinction. Many gated communities create a distinctive atmosphere by using architectural solutions and high-quality materials. They create an "affective ambience", characteristic of a space of consumption (GĄDECKI and SMIGIEL 2009). Landscape is another feature of representation that is applied to establish a positive image of these privatised urban spaces as well as functioning as a synonym for belonging and identification. Moreover, this helps to position gated communities as "a city within a city" as one billboard in Sofia named it or as a type of 
heterotopia in a Foucaultian sense (a type of other space) where one can escape the "chaos of Sofia" as interviewed developers and residents stated. ${ }^{13)}$

Professionalised representation is based on economic motives as well. The whole package of advertisement is used to valorise housing in order to create a market value in general and to attract international investors in particular. In fact, large segments of many gated communities in Sofia were sold en-bloc to international developers who subsequently tried to resell them to individual buyers.

"I don't know the ratio of people who are buying an apartment for living or as an investment. It is hard to tell, but anyway it is not important for us. I guess the ratio is quite equal." (Property Manager "Vitosha Tulip")

"Our product is designed for international clients plus the small percentage of Bulgarians who can afford it. The majority of the foreigners use it as income property. They want to rent it out while the Bulgarians want to use it as their first residence with their families and friends." (Sales Manager "Mount View Sofia")

Both citations reveal that the exchange value of housing is superior to the use value to put it in classic terms. However, this has contributed to a high vacancy rate that has even increased since 2008 in many gated communities. Vacancy rates range from 50 to 80 percent of the apartments in the majority of Sofia's gated communities that have either not been sold or are not being used (SMIGIEL 2016, p. 249). This contradictory aspect of capitalist housing production has a tremendous impact on everyday life inside and outside as empty and high-quality housing complexes occupy urban space while on the other hand overcrowding of flats is one of the highest in Sofia in comparison with EU-28 cities (World Bank 2017, p. 51). Furthermore, the global financial crisis increased the level of vacancy and emptiness since a number of projects remained unfinished.

"Most of these empty or unfinished projects had been financed by banks which somehow financed an investment plan presented by the developer. A lot of developers didn't make professional forecasts, so they can't pay back the loans to the banks. At the end the bank takes over the whole project and waits for better times." (General Manager "Residential Park Sofia").

Concerning recent developments, one can observe a kind of "consolidation", which means that the housing boom is over on the one hand, but construction has started again after the

\footnotetext{
13) "When thinking about the most crucial factors for moving here I can say that security is still a major issue. I mean the rules that we've introduced since the beginning. These regulations are very strict, but people are coming here, because of the rules. They are very detailed especially in terms of parking. So you will not find many cars in the complex because all houses have underground garages. In fact, you can park just temporarily in front of your house. And there are other rules in terms of where and how to walk your dog etc. But people are happy, and they tell me so many times. We moved here because of the strict rules. We don't want to live in such a chaotic environment like it exists in many public buildings in other parts of Sofia." (General Manager Residential Park Sofia).
} 
2008-2009 global financial crisis on the other. There are a few gated housing complexes which have been built or are currently under construction. ${ }^{14)}$ Most of them are located in the prestigious Southern parts of the city where 90 percent had been built before 2008 or further outside city limits (SMIGIEL 2016).

Another tendency is a growing number of short-term rentals among gated community apartments as a random sample indicated. ${ }^{15)}$ Although the level of "Airbnbification" is still rather modest in Sofia most short-term rental units are concentrated in gentrified or higher-income neighbourhoods (ROELOFSEN 2018). In fact, we could identify quite a number of apartments that are situated, for example, in some of the "self-organised" gated communities of the 1990s which indicates a shift towards commodification (see chapter 3.1.1). Since apartments are usually sold, owners can decide to rent them out individually.

\subsection{Kiev [Kyiv]}

In the case of Kiev, it should be emphasised that the housing estate market was affected by both the financial crisis of 2008-2009 and the political and armed conflict of 2013-2014. The latter significantly affected the dynamics and diversity of gated communities. In the post-crisis period, the dominant role shifted to large Ukrainian development companies. With political, military and economic shocks, the non-transparency of land and construction permits has somehow blocked foreign capital flows. Instead, different alliances of local stakeholders emerged.

Demand for gated communities is determined by local residents of Kiev, regional elites, and Ukrainian labour migrants who likewise buy housing in Kiev and the suburbs for (future) residency or as assets. To some extent, the last one is a manifestation of tele-urbanisation, a process of remotely controlled urbanisation (GENTILE et al. 2015). One more group of buyers is that of internally displaced people who independently (from the state programs) decide on the purchase of housing in Kiev.

The most common gated community post-crisis versions in Kiev are as follows: (i) improved versions of "cottage villages" in suburbia, (ii) gated residential complexes in the city neighbourhoods, and (iii) "club" and "conceptual" houses in the city centre and periphery.

\section{Improved versions of "cottage villages" in suburbia}

After 2009, the construction boom of "cottage villages" in the suburban area resumed, but with signs of selectivity, taking into account customer requirements. Moreover, in terms of volumes of new construction, "cottage villages" are less considerable in compare with

\footnotetext{
14) https://www.maxisofia.com/en/maxi_club_sequoia; https://www.youtube.com/watch?v=Wy7oTmbAEuA; https:// www.stone-hard.com/bulgaria/developments/bulgaria/region-sofia/developments-in-sofia/property-typeresidential/ (all retrieved May 5, 2020).

${ }^{15)}$ We used AirDNA data to identify the spatial location of short-term rentals as well as looking at gated communities that have been studied before (SMIGIEL 2016, p. 158).
} 
large residential complexes. At the same time, there is a trend towards significant expansion of gated communities into Kiev.

\section{Gated residential complexes in the city neighbourhoods}

A new version of the gated community which has acquired significant scale is a large fenced and guarded residential complex within the city limits. On the housing market it is called a "closed residential complex", namely a "complex" not a "community". This concept of "complex" implies a "package" of housing, infrastructure, public spaces, but to a lesser extent communication and relationships between residents.

If in ordinary residential complexes, housing is built first and then for a long time a set of infrastructure problems is solved, in the case of "closed residential complexes", housing construction is carried out in parallel with the social infrastructure. These gated complexes are promoted and popularised as places where one would have a feeling of comfort, security and seclusion, although in reality it often remains only attractive advertising with some manifestations of discomfort and crowding.

Developers emphasise that in such complexes residents will live "all together among each other", and they will have "space for a small community", where there are "almost no strangers". So, it actualises the concept of "them and us", encourages spatial segregation and creates some kind of residents' exclusivity in comparison with less successful people from neighbouring housing estates. "Closed residential complexes" have both a physical border (in the form of a fence that separates them from external dangers) and a social one ("our" and "not our" space, lack of interest and indifference to the inhabitants of the surrounding houses and neighbourhoods). The concepts of car-free courtyards, "Live. Work. Rest" (or "Live. Work. Play"), and "City Resort" are also actively promoted.

Location and surroundings play an important role for gated residential complexes in Kiev. Some of them are surrounded by former working-class neighbourhoods and Soviet-era housing estates. At first, they were not gated, but later, due to conflicts with the surrounding residents, they were gated to isolate themselves from unwanted (sometimes perceived as marginalised) neighbours. Therefore, such complexes become in fact "islands of civilisation in a sea of delay" (MEZENTSEv et al. 2019). Centrally located gated residential complexes are focused on isolation from city bustle and noise, located on the outskirts of the city and close to the natural (green) environment. They look much less contrasting to surrounding neighbourhoods in comparison with the first complexes, "bright spots on a grey urban fabric". It should be noted that the results of studies of the impact of fenced urban communities on the surrounding urban landscape and social relations mainly suggest that the spread of fencing practices does not always actually increase security and promote solidarity within the community (DRYAMOV and RYABCHUK 2019).

\section{"Club" and "conceptual" houses in the city centre and periphery}

The realisation of the projects of gated "club houses" also became larger after the financial crisis. In order to promote this type of a gated community, developers, in addition to the idea of "clubiness", use more sophisticated interpretations like a "special philosophy", or 
a "concept house" label. It goes beyond the closed club for affluent people but is rather a gated club for people with a common lifestyle. "Club housing" is understood to be one where "people like me" live. It is rather not so much joining the more affluent community but living in a community "with a similar philosophy of life", "in a circle of like-minded people", where the feeling of security is not determined by the height of the fences, but by the level of mutual trust.

Thus, the various types of gated communities after the financial crisis of 2008-2009 have acquired much larger visibility in the city, increasingly colonising urban space, creating alternative spaces, formally separated from the city problems, increasing fragmentation and (until recently absent) socio-spatial segregation:

"Fenced communities as a housing practice are spreading and developing in contemporary Kiev against the background of globalizing transformations of the city - gentrification, commercialization of public spaces, and crisis of urban planning in conditions of high visibility of social problems, namely: lack of social services, unsatisfactory environmental conditions, level of communal services, and security. All these problems contribute to the spread of housing practices of fenced communities as an alternative to the problematic 'body' of the city." (DrYAMOV and RYABCHUK 2019)

Urban policy in relation to increasing gatedness of urban space remains mainly indifferent. The interests of developers and private capital prevail over the priorities of socio-spatial justice. In the absence of a clear vision for future city development, the "gatedisation" of urban space could turn Kiev into a "patchwork city" with tension and mutual misunderstanding between residents of gated communities and other housing estates.

\section{Concluding remarks}

The paper traced different periods of gated community production in Kiev and Sofia. While the previous chapters have outlined the characteristics of gated community production in both cases separately highlighting main actors and their relationalities, this concluding chapter will focus on a brief comparison especially regarding what happened after 2008. Additionally, we will discuss whether gated communities can be seen as an indicator for peripheral urban development.

As the two short histories of gated housing development in Sofia and Kiev have shown, both cities experienced a decrease in gated community construction due to the global financial crisis in 2008. In recent years, housing construction as well as housing prices have increased again. Gated communities are part of this recovery. In both cases, large investors or large providers tend to dominate the market, but the scalar settings differ. While gated community production is quite heterogeneous in Sofia including local and global capital chains, international landlords, national subsidies and (local) urban planning regimes, gated community production in Kiev is predominantly organised along "national/local" lines in terms of capital chains and politico-institutional settings. 
However, these differences do not result from a different model of housing since privatisation of housing, private ownership and channelling private capital into real estate are major cornerstones of housing and urban policies in both contexts. Additionally, Sofia and Kiev are both capital cities that absorb the majority of (foreign) direct investment especially in real estate. Migration patterns are another similar feature as both capital cities attract the majority of internal migrations flows. ${ }^{16)}$ Moreover, both cities have experienced a variety of crisis of the last three decades that have strengthened the role of private solutions in variegated respects.

The lack of rule of law concerning urban planning regulations is another characteristic of Kiev and Sofia, which is associated with a rollback of the state since the early days of transformation. In fact, we can identify elements of a neoliberal-clientelist state where imbalanced power structures advantage private interests and intensify urban sprawl in both cases. Gated communities are part of this ongoing suburbanisation, which however is following different pathways in the last ten years in both cases.

Comparing development in the outskirts of both cities, one can observe a massive increase of gated settlements in the case of Kiev that enlarges the city limits substantially. The Sofia case is defined by a rather modest but also unregulated growth of gated suburban settlements. Still, one can conclude that gated housing has become a kind of standard way of housing and living in both cases. There is hardly any public debate concerning the loss of public space or other consequences of gated housing areas. In Kiev, a variety of gated neighbourhoods for different income strata emerged within city limits and its surrounding areas. Although newly constructed gated residential complexes may not dominate the entire housing markets, they mirror fragmentation or polarisation processes as well as they are highlighting new structures of order and control that are perceived as "a normal way of urbanisation".

Finally, yet importantly, gated communities make us reflect on the type of peripheral urbanisation that occurs in South-Eastern European cities. While a sustained discussion concerning this issue goes beyond the scope of this paper, we want to highlight briefly some aspects. First, gated communities can be considered a production of space that has appeared in many different spatial settings as a form of planetary urbanisation to use Neil BRENNER's (2018) conceptualisation. Second, gated communities need to be considered as glocalised housing products and therefore analysed concerning the global as well as local relationalities. Third, the portrayed cases reflect a kind of peripheral urban development in South-Eastern Europe in economic and socio-cultural terms.

This includes the role of informal structures that tend to direct urban development as control, regulation and long-term strategies are absent. It also comprises economic dependency on very few economic sectors (e.g. real estate) or capital flows (e.g. foreign remittances, foreign direct investments) for certain periods of time which might change quickly. Short periods of massive capital investment flows, for example, are followed by rapid phases of stagnation and reflect the extraction of capital in peripheral markets on the one hand. On the other hand, it highlights the peripheral position, as the extremes (boom and crisis) are more pronounced as for example in Western European markets. One could add

\footnotetext{
16) The Ukrainian case is different due to the additional inflow of internally displaced persons.
} 
that peripheral urbanisation includes a higher vulnerability of these cities in case of crisis. Fourth, peripheral urbanisation leads to a deepening of fragmented socio-spatial structures as gated communities start to act politically or will be declared new administrative units.

\section{References}

Ambrose P. (1991): The Housing Provision Chain as a Comparative Analytical Framework. In: Scandinavian Housing and Planning Research, 8 (2), pp. 91-104.

Atanasov V. (2010): PolItyka zhitlovoho budivnytstva v postradyanskii Ukrayini [Housing Policy in Post-Soviet Ukraine]. In: Spil'ne, 2, Transformatsii miskoho prostoru [Transformations of Urban Space], pp. 68-72. - https://commons.com.ua/uk/politika-zhitlovogo-budivnitstvav-pos/ (last access: August 16, 2020).

BIBIK N., DrIL N. (2017): Trends of Housing Construction Development in Ukraine: Retrospective and Contemporary Situation. In: Baltic Journal of Real Estate Economics and Construction Management, 5 (1), pp. 51-61.

Bodnér J. (2008): Becoming Bourgeois: (Postsocialist) Utopias of Isolation and Civilization. In: Davis M., Monk D. B. (eds.): Evil Paradises: Dreamworlds of Neoliberalism. New York: The New Press, pp. 140-151.

Bogdanov L. (2006): Eigentumsrechte und Wohnungsbau in Sofia [Property Rights and Residential Construction in Sofia]. In: Klingan K., KaPPERT I. (eds.): Sprung in die Stadt [Jump into Town]. Chişinău, Sofia, Pristina, Sarajevo, Warschau, Zagreb, Ljubljana. Köln: DuMont, pp. 126-133.

Botzem S., Doвusch L. (2012): Dienstleister der Finanzialisierung: Fragmentierte Organisation und kalkulierte Profite in der Immobilienwirtschaft [Service Providers of Financialisation: Fragmented Organisation and Calculated Profits in the Real Estate Industry]. In: Kölner Zeitschrift für Soziologie und Sozialpsychologie, 64 (4), pp. 673-700.

Brade I., Makhrova A, Nefedova T. (2014): Suburbanization of Moscow's Urban Region. In: StAnilov K., SÝKORA L. (eds.): Confronting Suburbanization: Urban Decentralization in Postsocialist Central and Eastern Europe. Chichester: John Wiley \& Sons, pp. 97-132.

Brenner N. (2018): Debating Planetary Urbanization: For an Engaged Pluralism. In: Environment and Planning D: Society and Space, 36 (3), pp. 570-590.

Colliers International (2018): Sofia. Residential Market Overview 2/2018. - https://www2.colliers. com/en-BG/Research/Residential-Market-Overview-H2-2018 (last access: May 7, 2020).

Commercial Property (2004): Sistema ipotechnogo kredytovaniia: v poiskakh konfyguratsii [Mortgage Lending System: In Search of Configuration]. - https://commercialproperty.ua/cparticles/sistema-ipotechnogo-kreditovaniya-v-poiskakh-konfiguratsii/ (last access: August 16, 2020).

Commercial Property (2009): Krizis i kottedzhnyie gorodki: neravnaia borba [The Crisis and Cottage Towns: An Unequal Struggle]. - https://commercialproperty.ua/analitics/krizis-i-kotte dzhnye-gorodki-neravnaya-borba/ (last access: August 16, 2020).

Dandolova I. (2014): Sofia After 1989: New Reality of Residential Development. In: Europa Regional, 11 (3-4), pp. 32-47.

Dryamov R. O., RYABChUK A. M. (2019): Konstruiuvannya ta vidtvorennia znachen pro ogorodzheni spilnoty Kyieva v reklamnomu dyskursi [Construction and Reproduction of Meanings of Gated Communities in Kiev in Advertising Discourses]. In: Naukovi zapysky Naukma. Sociologiya [Scientific Notes of Naukma. Sociology], 2, pp. 35-45. 
EBRD - European Bank for Reconstruction and Development (1999): Transition Report 1999: Ten Years of Transition. London: EBRD. - http://www.ebrd.com/downloads/research/transition/ TR99.pdf (last access: May 7, 2020).

Fedoriv P., Lomonosova N. (2019): Public Housing Policy in Ukraine: Current State and Prospects for Reform. Kiev [Kyiv]: CEDOS. - https://www.cedos.org.ua/en/articles/derzhavnazhytlova-polityka-v-ukraini-suchasnyi-stan-ta-perspektyvy-reformuvannia (last access: August 16, 2020).

Fernandez R., Aalbers M. B. (2016): Financialization and Housing: Between Globalization and Varieties of Capitalism. In: Competition \& Change, 20 (2), pp. 71-88. - https://doi.org/ 10.1177/1024529415623916.

GĄDECKI J. (2013): The Wild West. The Reality of Everyday Social Relations in Gated Communities in Poland. In: Cities, 35, pp. 174-180.

GąDeCKi J., Smigiel C. (2009): A Paradise Behind Gates and Walls: Gated Communities in Eastern Europe and the Promise of Happiness. In: Bartetzky A., Schalenberg M. (eds.): Urban Planning and the Pursuit of Happiness. Berlin: Jovis, pp. 198-217.

Gentile M., Salukvadze J., Gogishvili D. (2015): Newbuild Gentrification, Tele-Urbanization and Urban Growth: Placing the Cities of the Post-Communist South in the Gentrification Debate. In: Geografie, Czech Geographical Society, 120 (2), pp. 134-163. - https://doi. org/10.37040/geografie2015120020134.

Harvey D. (2001): Globalization and the "Spatial Fix". In: Geographische Revue, 3 (2), pp. 23-30.

HiRT S. (2007): Suburbanizing Sofia: Characteristics of Post-Socialist Peri-Urban Change. In: Urban Geography 28 (8), pp. 755-780.

HiRT S. (2012): Iron Curtains: Gates, Suburbs and Privatization of Space in the Postsocialist City. Malden/Oxford: Wiley-Blackwell.

Hirt S., Petrović M. (2011): The Belgrade Wall: The Proliferation of Gated Housing in the Serbian Capital after Socialism. In: International Journal of Urban and Regional Research, 35 (4), pp. $753-777$.

Ivanova M. N. (2009): Growing Through Debt and Inflation: An Inquiry into the Esoteric and Exoteric Aspects of Bulgaria's Currency Board. In: Debatte: Journal of Contemporary Central and Eastern Europe, 17 (2), pp. 161-179.

Kasianova Y. (2010): Koncha-Zaspa: selo glavnykh bogachei strany [Koncha-Zaspa: The Village of the Country's Main Wealthy People]. Glavkom, April 7, 2010. - https://glavcom.ua/publications/ 441-koncha-zaspa-selo-glavnyh-bogachej-strany.html (last access: August 16, 2020).

Kovács Z., Hegedüs G. (2014): Gated Communities as New Forms of Segregation in Post-socialist Budapest. In: Cities, 36, pp. 200-209.

KyJ M. J., PAL S. (2002): Housing in Ukraine: How Different is Kiev from Western Cities? In: Journal of East-West Business, 7 (2), pp. 85-106. - https://doi.org/10.1300/J097v07n02_05.

Lentz S. (2006): More Gates, Less Community? Guarded Housing in Russia. In: Glasze G., We-bsTER C., Frantz K. (eds.): Private Cities: Local and Global Perspectives. London: Routledge, pp. 206-222.

Liasheva A. (2018): Housing in Kiev: Why Don't We Have a Place to Live? In: Commons: Journal of Social Criticism. - https://longreads.tni.org/housing-in-kiev/(last access: August 16, 2020).

Maknrova A. G. (2007): Changing Housing Markets in Russian Cities. Case Study of Moscow, St. Petersburg and Kazan. In: Geographische Rundschau / International Edition, 3 (1), pp. 28-35.

Matznetter W., Mundt A. (2012): Housing and Welfare Regimes. In: Clapham D., Clark W., GiBb K. (eds.): The SAGE Handbook of Housing Studies. London: Sage publications, pp. 274-294. 
MRI - Metropolitan Research Institute (2017): Affordable Housing in Central and Eastern Europe: Identifying and Overcoming Constrains in New Member States. Budapest: MRI. - https:// ec.europa.eu/futurium/en/housing/affordable-housing-central-and-eastern-europe-identi fying-and-overcoming-constrains-new (last access: May 14, 2020).

Mezentsev K., Brade I., Mezentseva N. (2012): New Social and Economic Processes in Kyiv's Hinterland. In: Часопис соціально-економічної географіï [Journal of Socio-Economic Geography], 12 (1), pp. 156-160.

Mezentsev K., Pidgrushnyi G., Mezentseva N. (2015): Challenges of the Post-Soviet Development of Ukraine: Economic Transformations, Demographic Changes and Socio-Spatial Polarization. In: Henn S., Lang T., Sgibnev W., Ehrlich K. (eds.): Understanding Geographies of Polarization and Peripheralization. New York: Palgrave Macmillan, pp. 25-269. - https://doi.org/10.1057/9781137415080_14.

Mezentsev K., Gentile M., Mezentseva N., Stebletska I. (2019): An Island of Civilization in a Sea of Delay? Indifference and Fragmentation Along the Rugged Shorelines of Kiev's Newbuild Archipelago. In: Journal of Urban Affairs, 41 (5), pp. 654-678. - https://doi.org/ 10.1080/07352166.2018.1503544.

Mladenov C.; Dimitrov E., Kazakov B. (2008): Demographical Development of Bulgaria during the Transitional Period. In: Méditerranée, Journal of Mediterranean Geography, 110, pp. 117-123. - https://doi.org/10.4000/mediterranee.550.

National Statistical Institute, Republic of Bulgaria (2020): Statistical Data: Migration of the Population by Place of Residence, Districts, Age and Sex. Sofia: NSI. - https://www.nsi.bg/ en/content/6689/migration-population-place-residence-districts-age-and-sex (last access: October 20, 2020).

Natsionalnyi Bank Ukrayiny [National Bank of Ukraine] (2020): Zvit pro finansovu stabilnist [Financial Stability Report], December 2019. Kiev [Kyiv]: National Bank. - https://bank. gov.ua/ua/news/all/zvit-pro-finansovu-stabilnist-gruden-2019-roku (last access: August 16, 2020).

Pereverzieva A. V. (2016): Otsinka suchasnogo stanu zaluchennya inozemnykh investytsii v ekonomiku Ukrayiny [Assessment of the Current State of Attraction of Foreign Investments into Economy of Ukraine]. In: Visnyk Zaporizkoho natsionalnoho universytetu. Ekonomichni nauky [Bulletin of Zaporizhzhya National University, Economic Sciences], 1 (29), pp. $74-81$.

Polanska D. (2010): The Emergence of Gated Communities in Post-Communist Urban Context: and the Reasons for their Increasing Popularity. In: Journal of Housing and the Built Environment, 25 (3), pp. 295-312.

Pósfai Z. (2018): Reproducing Uneven Development on the Hungarian Housing Market. PhD Thesis, University of Szeged. - https://core.ac.uk/download/pdf/155771618.pdf (last access: May 7, 2020).

Pylypets O., Matiyash P. (2006): Housing Finance in Ukraine. In: OECD (ed.): Housing Finance Markets in Transition Economies: Trends and Challenges. Paris: OECD Publishing, pp. 269-279.

REAS, JLL Residential Advisory (2008): Residential Markets in Central European Capitals. - http:// www.reas.pl/index.php?pid $=202 \&$ fileid $=501$ (last access: December 12, 2013).

RedzIUK Y. V. (2009): Vplyv pryamykh inozemnykh investytsii na ekonomiku Ukrayiny [The Impact of Foreign Direct Investment on the Economy of Ukraine]. In: Naukovo-tekhnichna informatsiia [Scientific and Technical Information], 4/2009, pp. 20-26.

Renaud B. (1990): Housing Reform in Socialist Economies. Washington, D.C.: The World Bank (= World Bank Discussion Papers Series, 125). 
RiEDel S. (2003): Bulgarien zwischen Subsistenzwirtschaft und Weltmarkt. [Bulgaria between Subsistence Economy and Global Market]. In: Osteuropa. Zeitschrift für Gegenwartsfragen des Ostens [Eastern Europe. Journal for Contemporary Issues in the East], 53 (1), pp. 58-76.

Roelofsen M. (2018): Exploring the Socio-Spatial Inequalities of Airbnb in Sofia, Bulgaria. In: Erdkunde. Archive for Scientific Geography, 72 (4), pp. 313-327. - http://doi.org/10.3112/ erdkunde.2018.04.04.

Slobodian O., Fitisova A. (2018): Registering Domiciles in Ukraine: How the System affects Ukrainians. A Sociological Survey. Kiev [Kyiv]: CEDOS Think Tank. - https://cedos. org.ua/system/attachments/files/000/000/087/original/Registration_Domicile_Analytical_ Report_Engl_from_June_20_2019.pdf? 1561038021 (last access: August 16, 2020).

Smigiel C. (ed.) (2009): Gated and Guarded Housing in Eastern Europe. Leipzig: Leibniz-Institut für Länderkunde (IfL) (= Forum IfL, 11).

Smigiel C. (2014): Reprint of "The Production of Segregated Urban Landscapes: A Critical Analysis of Gated Communities in Sofia". In: Cities, 36, pp. 182-192.

SMigiel C. (2016): Raumproduktionen im südöstlichen Europa: Materialität, Symbolik und Alltag der Sofioter Gated Communities [Productions of Space in South-Eastern Europe: Materiality, Symbolism and Everyday Life of the Sofia Gated Communities. Münster: Westfälisches Dampfboot (= Raumproduktionen: Theorie und gesellschaftliche Praxis [Productions of Space: Theory and Societal Practice], 24).

Smith A. (2007): Articulating Neo-Liberalism: Diverse Economies and Everyday Life in "Post-Socialist" Cities. In: Leitner H., Peck J., Sheppard E. (eds.): Contesting Neoliberalism: Urban Frontiers. New York: Guilford Publications, pp. 204-222.

Stanilov K., Hirt S. (2014): Sprawling Sofia - Postsocialist Suburban Growth in the Bulgarian Capital. In: STANILOv K., SÝKOR L. (eds.): Confronting Suburbanization: Urban Decentralization in Postsocialist Central and Eastern Europe. Chichester: John Wiley \& Sons, pp. $163-191$.

Stanoeva E. (2010): Interpretations of the Ottoman Urban Legacy in the National Capital Building of Sofia (1878-1940). In: Gunzburger MaKaš E., Damljanović Conley T. (eds.): Capital Cities in the Aftermath of Empires: Planning in Central and Southeastern Europe. Abington/ New York: Routledge, pp. 91-107.

Stenning A., Smith A., Rochovská A., Świątek D. (2010): Domesticating Neo-Liberalism: Spaces of Economic Practice and Social Reproduction in Post-Socialist Cities. Oxford: Wiley-Blackwell.

Stiglitz J. E. (2002): Die Schatten der Globalisierung [German translation of the English original edition: Globalization and its Discontents]. Berlin: Siedler Verlag.

Stoyanov P., Frantz K. (2006): Gated Communities in Bulgaria: Interpreting a New Trend in Post-Communist Urban Development. In: GeoJournal, 66 (1), pp. 57-63.

Tosics I., Hegedüs J. (2003): Housing in South-Eastern Europe. In: Lowe S., Tsenkova S. (eds.): Housing Change in East and Central Europe. Aldershot: Ashgate Publishing, pp. 21-44.

USPALENKo V. I., TytaRENKo O. V. (2016): Ipotechne kredytuvannia v Ukrayini: problemy, perspektyvy rozvytku [Mortgage Lending in Ukraine: Problems, Prospects for Development]. In: Finansova ta kredytna diialnist: problemy teorii ta praktyky [Financial and Credit Activities: Problems of Theory and Practice], 1 (8), pp. 73-78.

Vesselinov, E. (2004): The Continuing "Wind of Change" in the Balkans: Sources of Housing Inequality in Bulgaria. In: Urban Studies, 41 (13), pp. 2601-2619.

VerTyL N. M. (2016): Paradoks rynku zhytla v Ukrayini ta Rosiyi [Paradox of Housing Market in Ukraine and Russian Federation]. In: Ekonomichnyi visnyk universytetu [Economic Bulletin of the University], 30 (1), pp. 42-48. 
World Bank (1993): Housing: Enabling Markets to Work, A World Bank Policy Paper. Washington, D.C.: World Bank.

World Bank (ed.) (2003): Sofia City Strategy. Sofia: Sofia Municipality and the Cities Alliance/ World Bank.

World Bank (2017): Bulgaria-Housing Sector Assessment. - http://documents.worldbank.org/curated/ en/776551508491315626/Bulgaria-Housing-sector-assessment-final-report (last access: May 14, 2020).

ZAPATRINA I. (2012): The Ukraine: Waiting Lists Without Housing. In: Hegedüs J., Lux M., Teller N. (eds.): Social Housing in Transition Countries. New York: Routledge, pp. 292-303.

Zeller C., Van-Hametner A., Smigiel C., Kautzschmann K. (2018): Wohnen in Österreich: Von der sozialen Infrastruktur zur Finanzanlage [Living in Austria: From Social Infrastructure to Financial Investment. In: PROKLA. Zeitschrift für kritische Sozialwissenschaft [PROKLA. Journal of Critical Social Science], 48 (4), pp. 597-616. - https://doi.org /10.32387/ prokla. v48i193.1148. 